\title{
NONDEDUCTIBLE CAPITAL LOSSES AND BONA FIDE SALES UNDER THE FEDERAL INCOME TAX
}

Taxation of capital gains and losses under the federal income tar has produced both ardent controversy and endless litigation. ${ }^{1}$ Opponents of such taxation contend that it retards the mobility of capital. They challenge its utility as a source of revenue.? Adherents, on the other hand, reply that capital gains constitute an obvious enrichment, and that a failure to consider them would ignore a logical source of public revenue and would diseriminate arbitrarily against other taxpayers.

There is a basic disagreement, among those who advocate the taxation of capital gains, over the means to be employed. ${ }^{3}$ Methods suggested are usually compromises between inclusion in taxable income of all annually accrued, though unrealized, gain or loss and, on the other extreme, the recognition of gains only when realized by sale or exchange. The former represents the accrual method. It involves a critical question of constitutionality and extremely difficult problems of valuation." The latter represents the realization method. It ignores price index changes and, as incorporated into the revenue law, permits the individual to avoid income taxes by the simple expedient of retaining until death those securities showing large capital gains. $\mathrm{By}$ attaching an artificial importance to the fact of sale as the determinant of capital gain or loss, it places a powerful weapon in the hands of the taxpayer to use and misuse in minimizing taxes; for the power to sell rests wholly within the taxpayer's control. This weapon, and the ability through it to create

1. See generally, Starons, Persomal Income Taxation (193S) 14\$-168; Retort of Srbconsumtee on Ways and Mfears on Proposed Reviston of tue Revenue Laws, 75th Cong., 3d Sess. (1938) 28-32; Kent, Taxation of Capital Gains and Losses (1938) 16 TAX M.ag. 389. For a critical exposition of foreign systems, see Haig. Taxation of Capital Gains, Wall St. Journal, March 23-April 13, 1937.

2. "The statistics of revenue controvert the allegation commonly made that there would be no net revenue loss over the full period of an economic eycle if capital gains should be relieved of all income taxation." REroRT, op. cit. stupra note 1, at 30. But sse Snoxs, op. cit. sipra note 1 , at 157 .

3. See REPORT, op. cit. supra note 1, at 32: Smoxs, op. cit. supra note 1, at 154; Twextieth Century Fund, Inc., Facing the Tax Psonles (1937) 431.

4. As to the constitutionality of taxing unrealized income, see Rerons, op. cil. surra note 1, at 32; cf. Eisner v. Macomber, 252 U. S. 1S9, 207 (1920). As to tasing income on the accrual basis, see MLagild, Taxible Incosre (1936) $166 \mathrm{ct}$ siq.; Srasoss, of cit. supra note 1, at 167-169 (suggesting a decennial inventory).

5. Snows, op. cit. supra note 1 , at 212 suggests taxing capital gains at death as if the securities were then sold. Compare INr. Rev. Conz $\$ 44$ (d) (1939) (ucing hair market value at time of distribution, other than sale, of installment obligations). Because the tax is progressive the prudent taxpayer would, through frequent vash sales, licep his basis as little below current market value as possible. Increased manipulation would put new emphasis on the capital loss problem. 
capital losses to offset taxable income, has presented the Government with a considerable problem.

The intensity of this problem varies with the usefulness to the taxpayer of a realized capital loss. Income and security price movements of course influence the utility of realized capital loss to the taxpayer; and limitations on the amount of loss deductible equally affect their availability. Under the 1934 Revenue Act, deductible losses were limited to capital gains plus $\$ 2,0000^{\circ}$ but individuals by the $1938 \mathrm{Act}^{\top}$ and corporations by the $1939 \mathrm{Act}^{8}$ are permitted full deduction ${ }^{9}$ of long term capital losses from all types of income. Further, on assets held more than five years, the percentage of loss that will be taken into account has been increased. ${ }^{10}$ To the extent that the taxpayer is permitted to select and identify the particular security sold, avoiding the "first in, first out" rule, the creation of capital loss is facilitated, and in this matter the courts have shown increasing liberality. ${ }^{11}$ These factors will tend steadily to enhance the value to the taxpayer of a realized capital loss.

Though permitting the taxpayer a free hand in timing the sale to his best tax advantage, Congress obviously intended that capital losses should be realized only by bona fide sales. ${ }^{12}$ In a number of transactions, however, individuals have sought legal recognition of deductible losses while retaining or regaining benefits which are normally lost in sale. Dominion over the asset may be retained where the vendor exercises control over the vendee,

6. 48 STAT. 714, 26 U.S. C. \$101(d) (1934). 47 STAT. 207 (1932), 26 U. S. C. $\S 117$ (a) (2) (1934) had limited losses to gains to prevent depression market losses from wiping out normal taxable income, but was repealed in NIRA \$218(a), 48 STAT. 209 (1933). Until the 1934 Act there was no corresponding limitation. But sec $\$ 23(r)$, 47 Stat. 179 (1932).

7. 52 Star. 500 (1938), INT. Rev. Code $\$ 117$ (d) (2) (1939). See generally Austin, Capital Gains and Losses Under the Revenue Act of 1938 (1939) 17 TAxes 131.

8. INT. Rev. Code $\$ 117$ (d) (1939) as amended by Pub. L. No. 155, 76th Cong., 1st Sess. (June 29, 1939) §212(a), but does not apply until tax year of 1940. Id. §229.

9. But see INT. Rev. Code $\S 117$ (c) (1939). Short term capital losses (asset held less than 18 months) are allowed only to the extent of short term capital gains. $\$ 117$ (d) as amended, supra note 8 (includes corporations). But see carry-over provision, $\$ 117$ (c) as amended. Cf. $\$ 23(\mathrm{r}), 47$ Stat. 179 (1932).

10. Compare 52 Stat. 500 (1938), Int. Rev. Code $\$ 117$ (b) (1939) with 48 Stat. 714, 26 U.S.C. $\$ 101$ (a) (1934). Amount of individual's capital gain or loss now recognized where asset is held up to 18 months, $100 \%$; 18 to 24 months, $662 / 3 \%$; ovcr 24 months, $50 \%$.

11. Identification by designation is now permitted as opposed to strict identity by certificate. Helvering v. Rankin, 295 U. S. 123 (1935). But intention to sell particular shares is not sufficient. Davidson v. Comm'r, 305 U. S. 44 (1938). See 2 PAUL \& Mertens, Law of Federal Incone Taxation (Supp. 1938) 180-190.

12. INT. REv. CoDE $\$ 23(\mathrm{~g})(1)$ (1939) merely says "sale or exchange." The courts supplied "bona fide," see Note (1936) 102 A. L. R. 505; and it is first mentioned in the current U. S. Treas. Reg. 101, Art. 23(e)-1. For case collections on matters here discussed, see 3 Prentice-Hall 1939 Fed. Tax Serv. II 13,701-13,754; 391 C. C. F. 1939 Fed. Tax Serv. Iा 195.41-195.5691; 392 id. Пा 887-888. 
either directly or through community of interest. The vendor may establish this element of control by the familiar tax aroiding device of creating another entity, corporate or trust, with which to deal. ${ }^{13}$ It may arise in the identity of interest of a family - individuals legally, but economically a group. ${ }^{14}$ To a lesser degree, it may be present in the ties of social or business friendship. ${ }^{15}$ Or the vendor may assure his ability to recover the asset through a contract or option to repurchase, an indication that he intended only a temporary change in the form of his asset.16 Patently, such transactions, although sales in form, are not final dispositions by parties "dealing at arm's length." 17 But with the evidence largely in the taxpayer's hands, the Treasury found the task of proving bad faith not only onerous but too frequently impossible. ${ }^{18}$

To meet this situation, Congress inaugurated legislation based on the premise that in certain types of transactions the likelihood of bad faith is sufficiently great to warrant their universal disregard as establishing tax deductions. Section $118,{ }^{10}$ enacted to stem the tide of year-end wash sales,, 0 denied deductible loss to any sale followed or preceded within 30 days by a repurchase of, or a contract or option to repurchase, substantially identical securities. Impelled by a depression-born ware of tax evasion, the Congress in 1934 denied deductible loss on sales between members of a family. ${ }^{21}$ For despite a set of objective criteria of good faith developed by the courts,

13. Personal holding companies and family trusts also avoid taxes by withholding earnings or dividing income. Hearings before Joint Commiltec on Tax Exasion asd Aroidance, 75th Cong., 1st Sess. (1937) 4, 188, 217, 264-285 (taxpayer created sisty-four trusts for benefit of wife and three children). See Jacobson and Johnson, Minimiming Income and Estafe Taxes: Family Trust, Corforation and Partnership (1936) 5 BroorIYN L. REv. 389.

14. "The solidarity of the family is to make it possible for the taxpayer to surrender title to another and keep dominion for himself, or if not technical dominion, at least the substance of enjoyment." Cardozo, J., in Burnet v. Wells, 289 U. S. 670,677 (1933).

15. E.g., mutual sales and repurchases of securities aggregating thirty millions in the 1929-1930 market, between duPont and Raskob, intimate associates. Pierre S. duPont, 37 B.T. A. 1198 (1938) (losses disallowed).

16. See I. T. 2257, V-1 Cuar. BuLl. 241 (1926).

17. " . . . alleged sales of property for the purpose of establishing losces must be real, valid transactions, definitely placing the legal and equitable ownership of the property alleged to have been sold out of the hands and out of the control of the seller." M. I. Stewart \& Co., 2 B. T. A. 737, 739 (1925).

18. H. R. Rep. No. 1546, 75th Cong., 1st Sess. (1937) 26.

19. INT. REv. Code $\$ 118$ (1939), first enacted, 43 STAT. 269, $2 \$ 3$ (1924).

20. "Where such sales and purchases were part of one plan, they were ineffective to produce deductible losses, but there remained the difficulty of proving that they were parts of one plan - more correctly of meeting proof by the taxpayer that they were not." Shoenberg v. Comm'r, 77 F. (2d) 446, 450 (C.C.A. Sth, 1935), cert. dericd, 296 U. S. 586 (1935).

21. 48 Stat. 691, 26 U. S. C. $\$ 24(a)(6)$ (1934).

22. Reviewed in John E. Zimmermann, 36 B. T. A. 279, 284-2S6 (1937). I. T. 1997, III-1 Cuxr. BuLs. 149 (1924), disallowing loss on a sale between spouses filing joint returns, was revoked by I. T. 2824, XIII-2 Cu2s. BuLL. 293 (1934). Taxing spouses 
the "boudoir sale" between husband and wife had long been a frequent source of trouble. Deductions were also disallowed on sales between an individual and a corporation where the former owned more than fifty percent of the stock, with those shares held by his family attributed to him for this purpose. ${ }^{23}$ Because this encouraged the creation of multiple holding companies designed to escape the limitation of the provision by rendering transactions entirely intercorporate, ${ }^{24}$ Section 24 (b) was further amended ${ }^{25}$ in 1937 to abolish losses on sales between two corporations more than 50 percent owned by or for an individual, where at least one of them was by statutory definition a personal holding company during the preceding tax year. Its application was expanded by ascribing proportionately to stockholder, partner or beneficiary the stock owned respectively by a corporation, partnership, estate or trust, and to a stockholder the stock his partner held in the corporation. In addition, deductions were prohibited on sales between grantor and fiduciary or fiduciary and beneficiary of a trust, and between fiduciaries of trusts having a common grantor.

The weaknesses in this type of legislative approach are only too apparent. When losses on a class of transaction are automatically disallowed because there is inherent in the relation between the parties a high probability of bad faith, a number of sales undertaken in good faith are condemned. ${ }^{20}$ New legislation ${ }^{27}$ will continue to embrace parties in progressively less closely affiliated relations, and the proportion of bona fide sales will increase. Consequently the law will interfere more and more with normal business relations. A method which reaches too many innocent people in order to catch avoiders is inappropriate. Further, as the law becomes more articulate, the bona fide

as a unit, suggested in Bruton, The Taration of Fanily Income (1932) 41 YALE L. J. 1172, would eliminate these sales. But see Hoeper v. Tax Commission, 284 U. S. 206 (1931) for possible unconstitutionality. The present rule seems to be that in a joint return short term capital gains of one spouse cannot be offset by short term capital losses of the other. For discussion of a related problem see Pierce v. Comm'r, 100 F. (2d) 397 (C. C. A. 2d, 1938). However, the rule is still being challenged. Walter C. Tanney, 39 B. T. A., Jan. 31, 1939 (appealed to 3d Circuit).

23. 48 STAT. 691, 26 U. S. C. \$24(a) (6) (1934).

24. See Hearings before Joint Committee on Tax Evasion and Avoidance, 75th Cong,, 1st Sess. (1937) 257. For an example see id. at 216-217.

25. 50 Stat. 827 (1937) as amended in 52 Stat. 464 (1938), Int. Rev. Cone $\$ 24$ (b) (1939).

26. Many family sales are made for other than the tax reason, and many more have been held bona fide in spite of it. See cases in John E. Zimmermann, 36 B. T. A. 279, 284-286 (1937) ; A. R. Glancy, 31 B.T. A. 236 (1934). MoNtgomerY, FEDERAL INCOME TAX HANDEOOK (1935) 513 disapproves of $\S 24(\mathrm{~b})$ for this reason.

27. "Should time reveal new stratagems are being devised to thwart the spirit and intent of the corrective legislation which the Congress may enact at this time, it is the purpose of your committee to frame such further legislation as may be necessary to checkmate them . . ." H. R. REP. No. 1546, 75th Cong., 1st Sess. (1937) 32. 
concept will be weakened in several ways. Despite Congressional denials, courts tend to rely on the explicit provisions as complete delimitation of good faith in these transactions, and the more sharply the line between avoidance and evasion is drawn, the closer the avoider may approach with inpunity.9.$^{29}$ There are always courts who see in the subsequent passage of a provision the tacit admission by Congress that the transaction disallowed was formerly valid, ${ }^{30}$ thus jeopardizing several years of tax cases still in litigation. And, while burdening a field of the law which is already too complex, these provisions offer no complete solution to the problem: they carve out a part of the zone of conflict, but leave the borderline case-always the hardest - untouched.

Scarcely more attractive is the opposite legislative approach, that of laws couched in the most general terms, leaving to commissioner and judge the task of spelling out their application. Typical of this kind of legislation is the suggestion that Section $24(\mathrm{~b})$ be repealed and that, without further supplementary legislation, there be substituted a provision denying losses "where the seller retains control, direct or indirect, over the property which is the subject of the sale." 31 Though it may be argued that this would provide needed flexibility, as yet the Treasury has shown no marlied success in administering this type of law. ${ }^{32}$ And not even the extensive rulings and case law necessary for practical administration could determine for certain the individual case. $^{33}$ In tax law there is an inevitable conflict between certainty

28. “. . . it is not intended by this amendment $[\$ 24(b)]$ to imply any legislative sanction of claiming deductions for losses on sales or exchanges not covered thereby where the transaction lacks the elements of good faith or finality, generally characterizing sales and exchanges of property." Id. at 26.

29. "But the courts are chary about giving avoiders too much chance to shape the facts of their transactions preliminarily in the light of definitely formulated rules. It may be more important that the law be indefinite than that it be just to those who are not avoiders . . ." Paul, Studies in Federil Taxition (First Series, 1937) 155.

30. See Madeira v. Comm'r, 9S F. (2d) 556, 557 (C.C.A. 3d, 1938); Kaspare Cohn Co., Itd., 35 B.T.A. 646,672 (1937). "The fact that hy the Rerenue Act of 1937 the law was changed so that it now prohibits the recognition of a loss resulting from a transaction between the grantor and the fiduciary of a trust merely serves as an indication that the Treasury Department has finally admitted that such a trancaction should, under the law then in effect, have been recognized as a valid one ... " (1938) 13 TEArP. L. Q. 133, 135.

31. Angell, Tax Ezrasion and Tas Avoidance (1938) 38 Cor. L. Rev. $80,95$.

32. In referring to INT. REv. CODE $\$ 102$ (1939), imposing a surtax on corporations who accumulate surplus to avoid taxes, Under Secretary of the Treasury Magill said, "On the whole, the experience with that section has not been very satisfactory, becauc? of the vague terminology." Hearings, supra note 13, at 205.

33. Eichholz, Should the Federal Income Tax Be Simplificd? (1939) $4 S$ YaLE L. J. 1200,1217 , strongly criticizing Angell's suggestion. "Moreover, the word 'control' has many subjective implications which are impossible to determine accurately in a specific case . . . No provisions of our revenue laws are more productive of irritation than those which cause taxability to depend upon subjective tests." Ibid. 
and fairness to each individual; one cannot be obtained without sacrificing the other. ${ }^{34}$ Furthermore, such a provision would return to litigation all those situations covered by current legislation, and any solution entailing increased resort to the courts is highly undesirable. The delay and expense of litigation is already one of the most distressing aspects of the federal tax system.

Taking a realistic view of the statutes here involved, however, their vices seem more apparent than real. Evidently they have caused no more than normal taxpayer disaffection, ${ }^{36}$ for the vast majority of transactions touched had no real purpose other than tax avoidance. In their favor, it can be said that the provisions have served to quiet a hitherto extensively used form of tax avoidance; and while experts may yet construct the sale to fall beyond their prohibition, inconvenience is itself an effective deterrent. As for the complexity of the statutes, there is solace in the thought that the average small taxpayer never sees the Revenue Act, and the larger taxpayer will require legal advice anyway for his more complicated transactions. ${ }^{37}$ Retention of the provisions in their present form appears the most reasonable solution, entrusting to the courts those cases which violate the spirit of the law, though not its letter.

In the case of the bona fide concept, however, the wealth of decisions has served only to increase the ambiguity. Contour is lost in a case law that borders on chaos. Too frequently the expression is used but to camouflage the absence of any substantial grounds for decision: it has magic powers to direct the light in which equivocal facts are to be viewed. ${ }^{38}$

Where the good faith of a loss-realizing sale is challenged, it is generally quite evident that the tax reduction motive predominated. It is agreed, however, that this cannot itself be made the basis of nondeductibility. Few courts fail to preface their opinions with the rule of Gregory v. Helvering, ${ }^{30}$ that the purpose to minimize or avoid taxes by a particular transaction will not prevent

34. See Paul, Selected Studies in Federal Taxation (Second Series, 1938) 300; Angell, supra note 31 , at 93.

35. On the average a Board of Tax appeals decision is handed down six years, a Circuit Court decision eight years, and a Supreme Court decision nine years, after the date of the return. Traynor, Administrative and Judicial Procedure for Fideral Income, Estate, and Gift Taxes-A Criticism and a Proposal (1938) 38 Cor. L. Rev. 1393. The flood of tax cases has led to a demand for reforms in procedure and court structure. Ibid.; see Jackson, Equity in the Administration of Federal Taxes (1935) 13 TAx MaG. 641, 686; but see Youngquist, Proposed Radical Changes in the Fedcral Tat Machinery (1939) 25 A. B. A. J. 291.

36. Private Communications to the Yale Law Journal. Of course it takes little imagination to conjure up the "hard" case. E.g., MonTgoMery, op. cit. supra note 26, at 514 .

37. Eichholz, supra note 33 , at 1220 .

38. In John T. Smith, 40 B.T.A., Aug. 15, 1939, the exhaustive record of sales kept by the taxpayer reinforced majority's finding that they were bona fide. Id. at 14. To the dissent they indicated how carefully he had devised his scheme, $i d$. at 26.

39. 293 U. S. 465,469 (1935). 
the transaction from affecting, as it otherwise would, the incidence of that tax. But they assert that discovery of such a purpose is a signal for scrutiny to determine whether the transaction is in actual fact what it appears to be in form. ${ }^{40}$ To a certain extent this question is governed by imponderables; its answer must depend in part on the instinctive moral reaction of the juige to the taxpayer's efforts. ${ }^{11}$ Certainly he may minimize his taxes, ${ }^{42}$ but he must take care not to offend the court's sense of fairness; if he tries a little too hard, if the picture is a little too complete, he will lose his ease. Thus judges may seize on the mere repetition of a certain transaction as indicating bad faith, ${ }^{43}$ though, logically, if bona fide the first time, it should lose nothing in repetition. But for the most part, the matter of good faith must turn on whether the taxpayer adds substance to the form of his transaction by his willingness to abide its normal consequences. Courts insist uron a final disposition of the property, involving the loss of control as well as title."4

The question then arises as to whether the sale is final. Eventual repurchase does not necessarily deny it that finality, for except as it is disallowed by Section 118, where repurchase occurs within thirty days, the finality of a sale must be judged by the original transaction as then conceived; subsequent events are relevant only as they may reveal original intention. The disqualifying element is the existence at the time of sale of a "plan" to repurchase, 45 and "plan" implies at least some arrangement with, or control over,

40. E.g., Helvering v. Johnson, 104 F. (2d) 140, 143 (C. C. A. Sth, 1939); Chisholm v. Comm'r, 79 F. (2d) 14, 15 (C.C. A. 2d, 1935); Note (1936) 101 A. L. R. 204, 205. But cf. Helvering v. Gen. Utilities \& Operating Co., 74 F. (2d) 972,976 (C. C. A. Ath, 1935).

41. "The mind rebels against the notion that Congress . . . was willing to foster an opportunity for juggling so facile and so obvious. . . . To such an attempt the reaction of an impartial mind is little short of instinctive that the deduction is unreasonable . . " Cardozo, J., in Woolford Realty Co. v. Rose, 286 U. S. 319,330 (1932).

42. Not only has he no duty not to, Helvering v. Gregory, 69 F. (2d) 809,810 (C. C. A. 2d, 1934); but it guides taxation into safer channels, Harrans, TAx AroroAXCE (2d ed. 1932) 3. "Furthermore, it (tax avoidance) is the only effective way most of us have of registering our opposition to extravagance in governmental expenditures." Montgonery, op. cit. supra note 26 , at ix.

43. ". . . the very repetition of the devices used deprives the particular and all transactions of reality." Harron's dissent in John T. Smith, 40 B. T. A., Aug. 15, 1939, at 25 . It is probable that the bad impression created by precise duplication would be circumvented by an inconsequential change in the circumstances surrounding the transaction.

44. Paul, Studies in Federal Taxation (First Series, 1937) 137; Chisholm r. Comm'r, 79 F. (2d) 14, 16 (C. C. A. 2d, 1935) and cases there cited.

45. "Two very recent cases [Comm'r v. Dyer, 74 F. (2d) 685 (C. C. A. 2d, 1935), cert. denied, 296 U. S. 586 (1935) and Marston v. Comm'r, 75 F. (2d) 936 (C. C.A. 2d, 1935) ], in the Second Circuit, taken together, reveal the rule as to sales and repurchases. In the Dyer Case, there were sales and repurchases hoth parts of an original entire plan, and the claimed deductions were denied. In the Marsten Case there was a sale with no intention or plan to repurchase, but there was a later repurchase, and 
the vendee to assure the ability to affect repurchase. For, even though admitted, the mere determination to buy the shares back in the open market is immaterial. Thus a sale is final if the shareholder risks his holdings in the open market. 46 The risk of financial loss from intervening market flucturitions, however, is no badge of finality or good faith, for even where the parties are. not so closely identified that the taxpayer gains as vendee that which he loses as vendor, ${ }^{47}$ the tax he saves may be greater than the loss which he risks. ${ }^{48}$

Were it certain that there was on the part of the vendor no coincident intention to repurchase, it would make no difference with regard to finality that he sold to a vendee within his control and that he subsequently reacquired the property. ${ }^{40}$ But the fact of repurchase under these circumstances crentes a strong suspicion that such intention was present, ${ }^{50}$ and the courts are in general properly skeptical of the taxpayer's disavowals; his actions speak louder than his words. ${ }^{51}$ Cases in which sales were upheld despite subsequent repurchase are distinguished, ${ }^{62}$ either by the long period of time preceding resale, ${ }^{53}$ or by an affirmative and convincing showing of lack of agree-

the claimed deduction on account of the sale was allowed." Shoenberg v. Comm'r, $77 \mathrm{~F}$. (2d) 446, 449 (C. C. A. 8th, 1935), cert. denied, 296 U. S. 586 (1935). Accord: Foster v. Comm'r, 96 F. (2d) 130 (C. C. A. 2d, 1938).

46. Samuel M. Vauclain, 16 B.T.A. 1005 (1929) (even though stock repurchased same day, prior to $\S 118$ ). Where husband sells securities on the market and wife immediately buys similar securities with her own money, is there a wash sale under $\$ 118$ ? An "indirect" sale between husband and wife under $\$ 24(\mathrm{~b})$ ? Probably neither. Sce Comm'r v. Behan, 90 F. (2d) 609 (C. C. A. 2d, 1937) ; Montgonerx, op. cit. supra note 26 , at 514. But if policy discourages immediate repurchase by the taxpayer, should he be permitted to achieve nearly the same benefits through immediate repurchase by one in close relation to him? $\$ 118$ might well be combined with $\$ 24(\mathrm{~b})$ and expanded to disallow loss where, within 30 days, there has been a purchase by persons in the relations there described. 1938).

47. Comm'r v. W. F. Trimble \& Sons Co., 98 F. (2d) 853 , 856, 858 (C. C. A. 3d,

48. Pierre S. duPont, 37 B. T. A. 1198 (1938).

49. Marston v. Comm'r, 75 F. (2d) 936 (C. C. A. 2d, 1935) (disclaimer of intention to repurchase reinforced by immediate resale); see Foster v. Comm'r, 96 F. (2d) 130, 133 (C. C. A. 2d, 1938).

50. "This design was too complete to be without designer." Pierre S. duPont, 37 B. T. A. 1198, 1266 (1938). But see Dwight C. Wheeler, 32 B. T. A. 909, 916 (1935).

51. Comm'r v. Dyer, 74 F. (2d) 685 (C. C. A. 2d, 1935), cert. devicd, 296 U. S. 586 (1935) ; Rand v. Helvering, 77 F. (2d) 450 (C. C. A. Sth, 1935); Powell v. Comm'r, 94 F. (2d) 483 (C. C. A. 1st, 1938). But courts sometimes naively accept the taxpayer's testimony. E.g., Comm'r v. W. F. Trimble \& Sons Co., 98 F. (2d) 853 (C. C. A. 3d, 1938) (companies under common control, repurchase after 37 days).

52. Pierre S. duPont, 37 B. T. A. 1198, 1257 (1938).

53. E.g., John E. Lonergan, 4 B. T. A. 1209 (1926); Gray-Barkley Co., 11 B. T. A. 499 (1928) (each more than three years); General Securities Co., 38 B.T.A., Aug. 16, 1938 (two years). 
ment between the parties. ${ }^{51}$ The rule might then be stated: to be wanting in finality, a transaction must involve both a sale to a sympathetic vendee and a coexistent intention to reacquire the property.

The requirement that the taxpayer divest himself not only of title but of control $^{\text {si }}$ is not so easily formulated. Section $24(b)$ disallows losses where certain relations exist between the parties, relations in which the element of control has been most subject to abuse. ${ }^{53}$ But excepting this provision. the mere fact that the vendor is in position to exert control over the vendee does not per se brand their transaction with had faith; it is still possible for such parties to deal "at arm's length." ar The ability to cuntrol a furchaser may be used in three ways. First, it may be employed in the proliminaries to a sale, as a method of bringing buyer and seller together. Thus it is miscible to eliminate the needless service and expense of broker and exchange, and to avoid a sacrifice sale where the market is not a ready one. If the sale that follows is otherwise bona fide, this use of control is hardly improper. Second, this control may be used to vary the toms of the sale from a competitive norm - typically a collusive reduction of price below real value to increase the deductible loss. ${ }^{60}$ Market value will sometimes furnish a simple, objective index to this misuse of the control relation.

Third, the ability to control may be employed by the seller to exercise dominion over the asset after the sale is complete, where by the nature of the asset, such dominion is of consequence to him. This use is manifestly

54. No contact between parties: Comm'r v. Neares, 81 F. (2d) 947 (C. C. A. 9th, 1936); Charles E. Mitchell, 32 B.T.A. 1093 (1935). Change of condition: Cale $v$ Helburn, 4 F. Supp. 230 (W. D. Ky. 1933) ; Comm'r v. Hales, 76 F. (2d) 916 (C. C. A. 7th, 1935).

55. "But taxation is not so much concerned with the refinements of title as it is with actual command over the property taxed ..." Holmes, $I$., in Corliss v. Bowers, 281 U. S. 376, 378 (1930); Nicholson v. Comm'r, 90 F. (2d) 978 (C. C. A. Sth, 1937); Chisholm v. Comm'r, 79 F. (2d) 14 (C. C. A. 2d, 1935), iert. devied, 295 U. S. 641 (1935).

56. See notes $13,14,15$, supra.

57. E.g., Moses W. Faitoute, 38 B. T. A., July 12, 1938; Jolin T. Smith, 39 B. T. A., Aug. 15, 1939; Note (1936) 102 A. L. R. 505. " . . . the act of two parting dealing at arm's length-which is the usual criterion, or at least an indispensable criterion of examination of the reality or bona fides of a transaction such as this." Pierre S. duPont, 37 B. T. A. 1198, 1238 (1938).

58. Comm'r v. W. F. Trimble \& Sons Co., 98 F. (2d) 853,856 (C. C. A. 3d, 1933).

59. Marston v. Comm'r, 75 F. (2d) 936 (C. C. A. 2d, 1935); General Securities Co., 38 B. T. A., Aug. 16, 1938.

60. Fruit Belt Tel. Co., 22 B.T.A. 440 (1931). Sale for nominal sum: Comm'r v. Ehrhart, 82 F. (2d) 338 (C. C. A. 5th, 1936); Grace A. Covan, Exr., 30 B.T.A. 296 (1934), aff'd S8 F. (2d) 1007 (C. C. A. 6th, 1937) (memo); cf. Reginald Findie, 39 B. T. A., March 3, 1939.

Large blocks of securities raise special problems of valuation. See General Securities Co., 38 B.T.A., Aug. 16, 1938; Peters, The Fair Marlet I"alue of Blocls of Shet: (1939) 17 TAXes 17. 
inconsistent with arm's length dealing, although in application the terms "dominion" and "consequence" obviously defy precise definition. Exercise of dominion may be active, as in forcing the vendee to vote the stock or handle the property in accord with the vendor's wishes; ${ }^{01}$ or it may be passive, as a mere restraint on further alienation. ${ }^{62}$ If dominion were of such consequence to the vendor that he would not have sold to other than a controlled vendee, then the loss should be disallowed. ${ }^{63}$ The importance of dominion to the vendor may be determined by the nature of the asset: controlling, as opposed to minority interests; ${ }^{64}$ voting stock as distinguished from bonds and nonvoting shares; or physical assets vital to the conduct of the vendor's affairs. ${ }^{05}$ Tax evasion by means of a block of securities controlling an important operating subsidiary, shuttled between related companies, ${ }^{60}$ thus would not be permitted, for its sale to third parties would hardly have been contemplated. Nor would considerations of this nature greatly increase administrative problems, for transactions involving large blocks of securities or holdings in unlisted, family corporations are already subject to scrutiny by revenue officers.

That no court has given complete expression to this concept is due in part to the doctrine of corporate entity, from which source have stemmed the most serious structural faults of capital gains taxation. ${ }^{67}$ For where corporate transactions are involved, to recognize control is to violate the rule that a corporation will be regarded as an entity entirely distinct from those who

61. See George N. Crouse, 26 B. T. A. 477,479 (1932). Vendor may even retain possession. Esperson v. Comm'r, 49 F. (2d) 259 (C. C. A. 5th, 1931), cert. denied, 284 U. S. 658 (1931); Nicholson v. Comm'r, 90 F. (2d) 978 (C. C. A. 8th, 1937) (after "selling" securities to son-in-law, vendor pledged them with his broker).

62. As in the case of family corporations. See Madeira v. Comm'r, $98 \mathrm{~F}$. (2d) 556 (C. C. A. 3d, 1938).

63. Wickwire v. United States, 27 F. Supp. 724 (E. D. Mich. 1939). But cf. Helvering v. Johnson, 104 F. (2d) 140 (C. C.A. 8th, 1939). Offers made to third persons would be relevant. St. Louis Union Trust Co. v. United States, 82 F. (2d) 61 (C.C.A. 8th, 1936); Marston v. Comm'r, 75 F. (2d) 936 (C. C. A. 2d, 1935) (sale at auction).

64. See Comm'r v. W. F. Trimble \& Sons Co., 98 F. (2d) 853,856 (C. C. A. 3d, 1938).

65. E.g., Glenwood Hotel Co., 5 B. T. A. 985 (1926).

66. Hearings before Joint Conmittee on Tax Evasion and Avoidance, 75th Cong., 1st Sess. (1937) 216. The use of commonly controlled corporations to avoid taxes suggests application of Int. Rev. Cone $\$ 45$ (1939). See Asiatic Petroleum Co. v. Comm'r, 79 F. (2d) 234 (C. C. A. 2d, 1935), cert. denied, 296 U. S. 645, 664 (1935) (\$ 45 prevents avoidance as well as evasion); 4 Paul \& Mertens, Law of Federal Income Taxation (1934) $\$ 38.98$; U. S. Treas. Reg. 101, art. 45-1. It would seem to allow denial of losses thus established but in General Industries Corp., 35 B.T. A. 615 (1937), by an unnecessarily narrow construction it was ruled otherwise. Reversal would permit the Treasury to avoid difficult problems in disregarding corporate entity (discussed post).

67. Simons, op. cit. sitpra note 1 , at 185 et seq. See RePort, op. cit. sipra note 1, at 2-3. For discussion of a suggestion to tax corporations as partnerships, Simovs, supra, 189-195. Generally, see 5 PAUL \& MERTENS, op. cit. supra note $66, \$ \$ 53.18-53.23$; Finkelstein, The Corporate Entity and the Income Tax (1935) 44 YALE L. J. 436. 
own and control it. Any logical consistency in applying the canon, Substance, not form, will control, is thus impossible, for the corporation is entirely a creature of form. The problem appears in so many variations that no comprehensive criterion has been developed; opinions are merely prefaced with the observation that the corporate entity will be disregarded "only where warranted by exceptional circumstance." os Beyond this there is little accord among the decisions as to what characterizes these circumstances in the case of a sale to establish a capital loss.

Complete ownership by a single individual is, alone, not enough. ${ }^{69}$ Some courts have turned a decision on the general nature and purpose of the corporation involved: if created to serve a business purpose, the corporate entity will be observed; if used only for tax avoidance, it will be disregarded. ${ }^{70}$ But while corporate purpose is determinative in reorganization cases, 71 it offers little clue to the part played by the corporation in a particular transaction. If the taxpayer is in control, he may rig his sale as well with an active company as with a dummy; and the same corporate entity has been disregarded in some transactions, not in others. ${ }^{2}$ Some opinions emphasize the necessity of observing all the formalities of sale, and would deny the entity where transactions are conducted entirely by book entry, and without formal stock: transfers. ${ }^{73}$ But if the substance canon has any meaning, the decision should not turn on matters that are largely form.

68. Burnet v. Clark, 287 U. S. 410, 415 (1932); Burnet v. Commonwealth Improvement Co., 287 U. S. 415, 419 (1932); Note (1936) 102 A. L. R. 505 . "In these casez the rule, if it can be called a rule, is frequently announced that the entity will be disregarded when it is necessary to promote justice or to obviate inequitable results." Fuller, The Incorporated Individual: A Study of the One-1Ian Company (1933) 51 Hars: L. REv. 1373, 1402.

69. Comm'r v. Eldridge, 79 F. (2d) 629 (C. C. A. 9th, 1935). See Smith v. Higgina, 102 F. (2d) 456 (C. C. A. 2d, 1939); (1938) 52 HARv. L. Rev. 325 . Because I:*t. RE: CODE $\$ 24(b)$ does not by its terms cover all transactions in which working control of a corporation is a factor, the general lines drawn in prior case law are still controlling.

70. Helvering v. Johnson, 104 F. (2d) 140 (C. C.A. Sth, 1939); (1939) 52 HAss: L. Rev. 1179. "The avoidance or suspension of tases is not a business." Electrieal Securities Corp. v. Comm'r, 92 F. (2d) 593, 595 (C. C. A. 2d, 1937). Finkelstein, supra note 67, divides corporations into "normal and convenient" and "unusual and unnescessary."

71. Gregory v. Helvering, 293 U. S. 465 (1935) : Sandberg. The Incame Tax Sut sidy to "Reorganizations" (193S) 38 CoL. L. REv. 98; Fahey, Income Tax Definition of "Reorganization" (1939) 39 COL. L. REv. 933, 937-946. While it might be claimed that the concept here developed would, in certain transactions [c.a., MFarjory T. Hardwicls, 33 B. T. A. 249 (1935), (1936) 30 Ir.. L. REv. 946] expand the type of loss dicallowance so closely restricted in $\$ 112$ (b) (5), it should be observed that in a slightly less degree this is also true of $\$ 24(\mathrm{~b})(1)(B)$.

72. Foster v. Comm'r, 96 F. (2d) 130 (C. C. A. 2d, 1938).

73. Dissent in John T. Smith, 40 B.T. A., Aug. 15, 1939; cf. Comm'r v. XreCreery, 83 F. (2d) 817 (C. C. A. 9th, 1936). But cf. Corrado \& Galiardi, Ine., 22 B. T. A. 847 (1931). 
Still other courts would observe the corporate entity where the stockholder has not used his power of control to the injury of the corporation. ${ }^{74}$ If the price is right, however, retention of dominion by the vendor need entail no financial disadvantage to company or minority stockholder. The analysis of the uses of control outlined above suggests one solution to the corporate dilemma. The doctrine of corporate entity permits a person to create a separate entity and to deal with it at arm's length without having its acts attributed to him. ${ }^{75}$ Where, through an improper use of control his transactions are inconsistent with arm's length dealing, he disables himself by his own act from invoking the protection of the corporate entity, and the doctrine offers him no assistance. ${ }^{76}$

Determination of the good faith underlying a capital loss, whether individual or corporate, should thus entail two inquiries: first, does there exist by dint of stock ownership or other relation, the ability in one party to control the other; second, in the immediate transaction, was this control element improperly used to vary the terms of sale from a competitive norm or to retain dominion over the asset? ${ }^{77}$ One cannot minimize the difficulty of factual contradiction which must often hinder an attempt to answer these two questions. But if all courts would pose the issue in these terms, the facts in time might marshall themselves into a fairly crystallized case law. It would scem wiser to look for progress in this direction, rather than once more to revise the statutes and subject taxpayers again to a host of first impression litigation.

74. Helvering v. Johnson, 104 F. (2d) 140 (C. C. A. 8th, 1939); John T. Smith, 40 B. T. A., Aug. 15, 1939, at 14.

75. "A ledding purpose of such statutes [incorporation laws] and of those who act under them is to interpose a nonconductor, through which in matters of contract it is impossible to see the men behind." Donnell v. Herring-Hall-Marvin Safe Co., 208 U. S. 267,273 (1908).

76. ". . . Where stock ownership has been resorted to, not for the purpose of participating in the affairs of a corporation in the normal and usual manner, but for the purpose of controlling the corporation and dominating its management and affairs so that it may be used as a mere agency, tool, or instrumentality of the owning corporation or corporations, the courts will disregard the fiction of the separate corporate entity and deal with the substance of the transactions in such manner as the justice of the case may require." Ford Motor Co. v. United States, 9 F. Supp. 590, 600 (Ct. Cl. 1935), cert. denied, 296 U. S. 636 (1935).

77. INT. REv. CoDE $\S 24(\mathrm{~b})$ and $\S 118$ merely deny losses, and it has been gencrally assumed that a capital gain may be established by a sale to the taxpayer's wife, or by a wash sale. E.g., MONTGOMERY, op. cit. supra note 26, at 520. But assume that a taxpayer realizes a capital gain in a wash sale for the purpose of using up an available net short term capital loss (deductible only from short term gains). In a subsequent sale of the asset may he take advantage of the new, higher basis to limit his taxable gain? It would seem that according to the bona fide concept he cannot, for the basis was not established by a final disposition made in good faith; and neither estoppel nor the statute of limitations will help him. But in practice, the Treasury apparently has not yet attempted to apply this reasoning. 